\begin{tabular}{ll}
\hline \hline MINING AND METALLURGY INSTITUTE BOR & ISSN: 2334-8836 (Štampano izdanje) \\
UDK: 622 & ISSN: 2406-1395 (Online) \\
\hline \hline
\end{tabular}

\title{
POSSIBILITY OF Pb-Zn ORE EXPLORATION IN THE DISTRICT PLAKAONICA II OF THE MINE CRNAC ${ }^{* *}$
}

\begin{abstract}
Within the rational use of mineral resources in the Pb-Zn mine Crnac, as well as the sequence of ore mining by strike of mineralization and depth of slope, this work presents the possibilities of extensions the ore field Crnac to the surrounding districts, in this case the district Plakaonica II. The applied methodologies of exploration are geological exploration works and mining exploration activities.

This work presents the exploration results obtained by interpolation of data from exploratory drill holes and exploratory mining operations in the district Plakaonica II.

Keywords: lead and zinc, exploration works, drilling exploratory drill holes, mining exploration operations, mining structures, exploration
\end{abstract}

\section{INTRODUCTION}

The area of the deposit Crnac is hilly and intersected by deep streams and ravines. The mine Crnac is at a relatively low altitude of 600 - 900 meters. It is located on the mountain Rogozna in the valley of the Crnacka River, left tributary of the Ibar. With the valley of the Josanicka River, i.e. the Crnacka River in the upper flow, the mine Crnac is connected with the facilities for ore processing in Leposavic with asphalt road $15 \mathrm{~km}$ long. The area of ore deposit has a mild climate. Heavy rain declines in the winter do not cause greater difficulties in ore transport.

The deposit Crnac was opened after ten years of intensive exploration by surface drilling, and mining operations in the period from 1957 to 1968 by the Geological Department of mine and lead and zinc smelter "Trepca" - Zvečan. The opening of the mine Crnac has contributed to the increase in raw material base of lead and zinc as the basic raw materials for the needs of metallurgical plants and newly constructed processing capacities of the Combine "Trepca" based on these metals. The opening of the mine Crnac with relatively high content of lead and zinc metal is a major incentive to development of an underdeveloped area such as the territory of the municipality of Leposavic.

Since its beginning or since 1968, the mine Crnac is a part of the organizational unit of the mines and flotation "Kopaonik" Leposavic. The current unfavorable situation of raw material base of the aforementioned organizational unit as well as the Combine "Trepca" in general, and growing needs for quality processing capacities, require further and more intensive exploration works both in the deposit and in its wider area.

\footnotetext{
* University in Priština with temporary headquarters in Kosovska Mitrovica, Faculty of Technical Sciencies, Kosovska Mitrovica, Kneza Miloša 7, blagojenedeljkovic@yahoo.com

** The realized exploration was funded by the Ministry of Education, Science and Technological Development of the Republic of Serbia (Project No. III43007, Project No. TR 33045).
} 


\section{DESCRIPTION OF THE DEPOSIT}

CRNAC and PLAKAONICA represent a system of fault zones and wires, genetically and temporally identical, so that they have great similarity by the mineralization type. The ore is mostly deposited in amphibolites, while now it is in a serpentine quantitatively and qualitatively the ore of subordinated importance. The ore veins have lenticular thickening and wedge out per strike and dip. Often, thin veins are met in some thicker wires, in order to diverge and wedge out. Individually thin and mineralized veins can be grouped into the ore zones, giving ore bodies with thickness up to $10 \mathrm{~m}$, with metal content within the limits of viability of exploitation. Smaller veins and veinlets as well as impregnation sometimes build a network and give mineralization of stockwork type [2].

The system of mineral veins is connected to the fault zones and cracks, striking NE - SW while the slopes are different, the ore veins sometimes divergently diverge at deeper levels, because one declines on the NW, and the other on the SE.

The ore zone is connected to contact of amphibolite serpentinite or diabase-chent series, which has the fault zones and dacite dikes, they decline to the SE. There are ore strings (eg, subsoil wires 3 and 4) with pad on the opposite side, or declineing towards NW. A higher number of mineral ore veins as well as the ore veins in the Plaonicki district decline towards NW. The decline angles of ore veins are variable and range within the limits of between $60^{\circ}$ and $90^{\circ}$.

In the ore association of the ore deposit deposit Crnac, the following essential minerals are identified: galena, sphalerite and pyrite, and subordinated chalcopyrite, arsenopyrite and pirhotin [1]. From the gangue minerals, predominatly were found quartz and calcite, and rarely rhodochrosite. In subsequent tests, the presence of iridium (2 $114 \mathrm{~g} / \mathrm{t})$ and selenium $(4.7 \mathrm{~g} / \mathrm{t})$ in individual sulphide minerals of lead and zinc. Scantily realized research the mineral paragenesis in the deposit points out the absence of ore and non-ore minerals characteristic for the contact-metasomatic or transitional contactmetasomatic-hydrothermal processes that preceded the main stage of hydrothermal processes in the formation of deposit. The absence of such phenomena and processes that preceded them show the conditions of formation the typical hydrothermal deposit mezothermal phase in which multi-stage was absent with characteristic successions that characterize the transition contactmetasomatic-hydrothermal lead-zinc deposits of the Kopaonik ore region. Explanations, associated with different colored sphalerites as the evidence of presence the epithermal processes in the deposit are not sufficient and should be substantiated by more complete and versatile tests. Until now, the presence of two succession of hydrothermal area of deposition is macroscopically observed in deposit. First, processes of depositing huge silicate and less silicon-carbonate formations, formed mainly at the expense of serpentinite in contact with their gabbro amphibolites and volcanic cover the cradle and Rogozna, correspond to the pre-ore stage. This association of rocks is mostly formed of opal-chalcedonian mass and amorphous silicon with higher or lower concentrations of pyrite, which in general can be considered sterile from an economic standpoint. The second main phase of depositing is represented by described ore minerals of mezzothermal stage with economic mineralization of lead and zinc, whose concentration in the appropriate structures of silicon masses is manifested as the ore bodies with the economic content of useful metals [2].

Considering the established successions and mineral paragenesis, the positional relationship of deposit and ore bodies with volcanic breakthroughs of the Tertiary age and clear hydrothermal processes, that approach to the conditions and deposits of the ore field Koporić - Jelakce, the deposit is classified as a type of hydrothermal deposits predominantly of mezothernal succession, genetically related to the process of tertiary metallogeny. 


\section{OPENING THE DEPOSIT CRNAC}

Opening the deposit CRNAC (Figure 1) was carried out in two phases. The first phase was in the period from 1957 - 1968 and included a level above $862 \mathrm{~m}$ and the second phase of opening from 1968 - 1980 from level $600 \mathrm{~m}$ - the Gnježdanski adit [3].

The ore deposit CRNAC above $862 \mathrm{~m}$ was opened by the system of adits, which at the same time represent the levels of the mine horizons as follows [3]:

- 0 - horizon at level $1.062 \mathrm{~m}$

- I - horizon at level $996.2 \mathrm{~m}$

- II - horizon at level $944.7 \mathrm{~m}$

- III - horizon at level $902 \mathrm{~m}$

- IV - horizon at level $862 \mathrm{~m}$

The first, second and fourth horizon were opened by adits from the surface (given elevations related to the elevations of the entrance into adits), while the third horizon was opened from the IV horizon by the system of raises as sub-level [3].

Next to the entrance of adit No. 4 (elevation 862), economically significant veins are labeled with ordinal numbers 1 - 17. As already mentioned, they have very sharply decline towards SE with decline angle of about $80^{\circ}$. They have the same morphological features as the other ore veins and remaining as the most important their ability to retain relatively good continuity, both by strike and by decline [3].

The fourth (IV) horizon has long been the main horizon, because the entire ore transport was done along it ore, the ore haulage to the surface was done over this adit. In addition, the entire delivery of materials required for the work was performed from the IV horizon; the main power grid is now on the horizon (compressed air, technical water and electrical energy) [3].

Opening of deposit below the level of $862 \mathrm{~m}$ was done by a system of mining operations of capital importance for the whole mine with the aim of undertaking a deep part of the deposit. For this purpose, the adit Gnježdane, length 3,781 m, was made. The blind service shaft was made at the level of $600 \mathrm{~m}$ to the level of $862 \mathrm{~m}$ level which six filling stations were made, as well as [3]:

- IV - horizon (K. $867.00 \mathrm{~m}$ )

- V - horizon (K. $818.00 \mathrm{~m})$

- VI - horizon (K. $768.00 \mathrm{~m})$

- VII - horizon (K. $718.00 \mathrm{~m})$

- VIII - horizon (K. $668.00 \mathrm{~m})$

- IX - horizon (K. $609.89 \mathrm{~m}$ ) pit bank at the level of adit

The haulage machine of the system "KEPE" is in the hall, which is located directly above the tower, and at $23.5 \mathrm{~m}$ above the filling station of the IV horizon [3].

The central ore chute - use for ore lowering from the pit to the level of the IX horizon - to the level of the adit "Gnježdane" [3].

\section{DEGREE OF EXPORATION THE DISTRICT "PLAKAONICA II"}

Exploration of this mineral structure was carried out in the period from 1983 to 1994. A large number of drill holes was made before the opening of the mine Crnac. In order to define the mineral structures located south of the English adit, in 1983, four drill holes were done (B -55, B - 54, B - 53 and B - 52) in the three profiles, whose results are positive or all intersected the mineral structures in several levels, but with insufficient number of data for calculation of reserves. Development the new exploratory drill holes from surface was approached in 1994, with the aim of better defining the exploration area as well as the re-categorization the ore reserves [3].

The positive results were obtained by drill holes B-55, B-56, B-57, B-58 and B-59 in four profiles at distance of $50 \mathrm{~m}$. All five drill holes drilled several mineral structure, which made it possible to transfer the reserves of $\mathrm{C} 2$ category into a higher category $\mathrm{C} 1$. By development the adit at elevation of $945 \mathrm{~m}$ and pit drill holes from this adit B-1/87, B-2/87, 
B-3/87, B-4/87 with the direction of drilling towards PLAKAONICA I, or mineral veins 13 and 15 , it can be concluded from profile that there is a broader sterile space between these two mineral structures (Figure 2) [3].

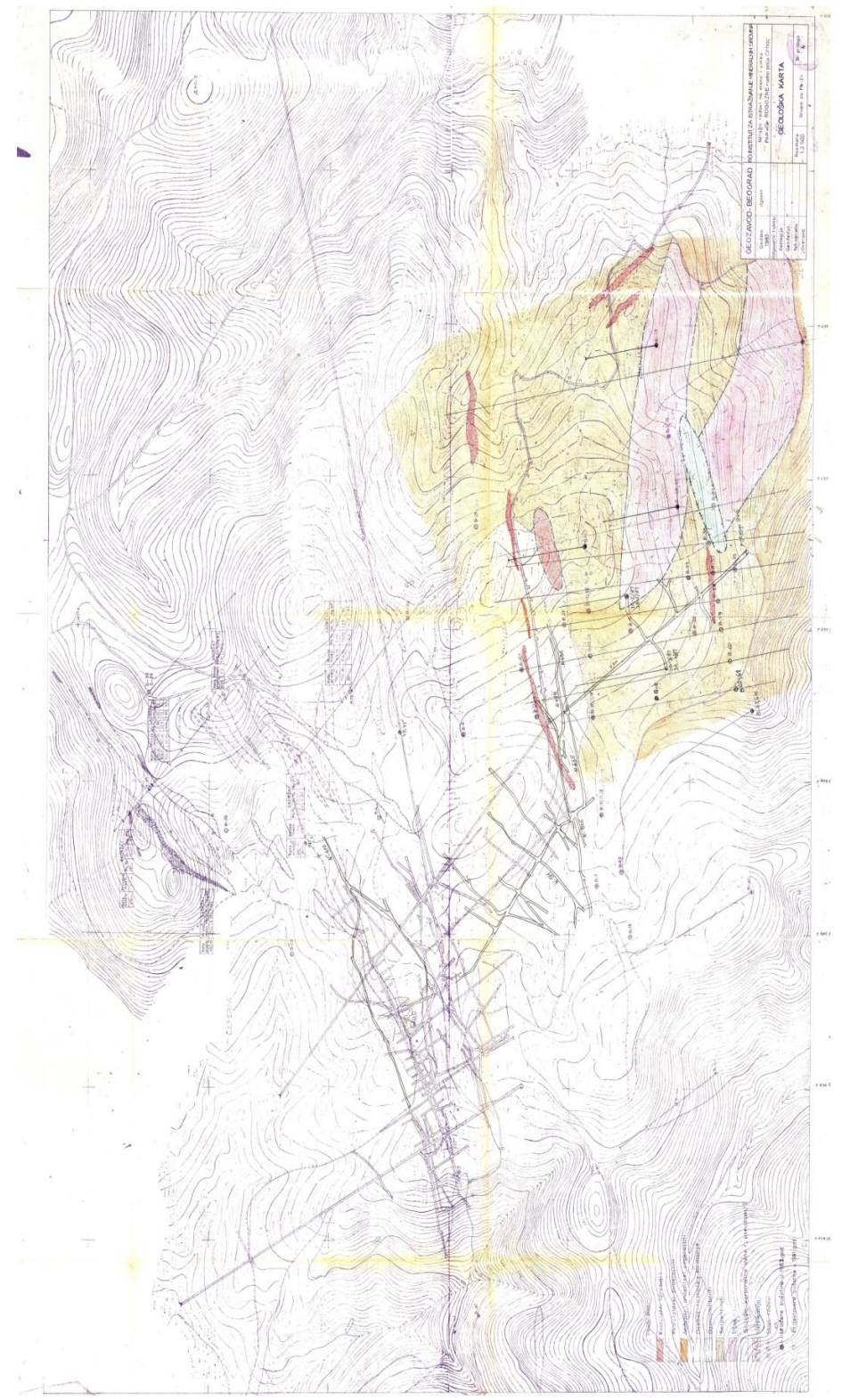

Figure 1 Map of the deposit with the layout plan of the pit CRNAC with given horizons

In 1984, four drill holes B-52, B-53, B-54 and B-55 were made in this district. The obtained data from these drill holes have established the reserves of $\mathrm{C} 2$ cate gory of $498,600 \mathrm{t}$ of ore with $4.41 \%$ lead, $4.12 \%$ zinc and $51 \mathrm{~g} / \mathrm{t}$ silver [4].

Spatially speaking, except the drill hole B-55, the other three are several hundred 
meters distant from designed corridor in this district, "PLAKAONICA II". However, all these drill holes cut in several levels several mineralizations with significant economic contents of metals [4].

- Drill hole B - 55 was designed with the aim to verify the strike of mineral structure drilled by drill holes B - 48 . The drill hole drilled serpentine, two quartz latite dikes, amphibolite schist, gneisses and four economically important mineral intervals.
- The first ore interval and the most powerful was drilled at depth of 49.8 to $70.8 \mathrm{~m}$ of apparent thickness ranging from $23 \mathrm{~m}$ and metal content in the ore is $5.51 \%$ lead, $4.21 \%$ zinc and $47 \mathrm{~g} / \mathrm{t}$ silver. Spatial ore is deposited in the intensely silicified serpentinite (siliconcarbonate ore) in contact with quartz latite.

- The second ore interval of apparent thickness of about $4 \mathrm{~m}$ with metal content of $4.0 \%$ lead, $4.09 \%$ zinc and $58 \mathrm{~g} / \mathrm{t}$ silver.

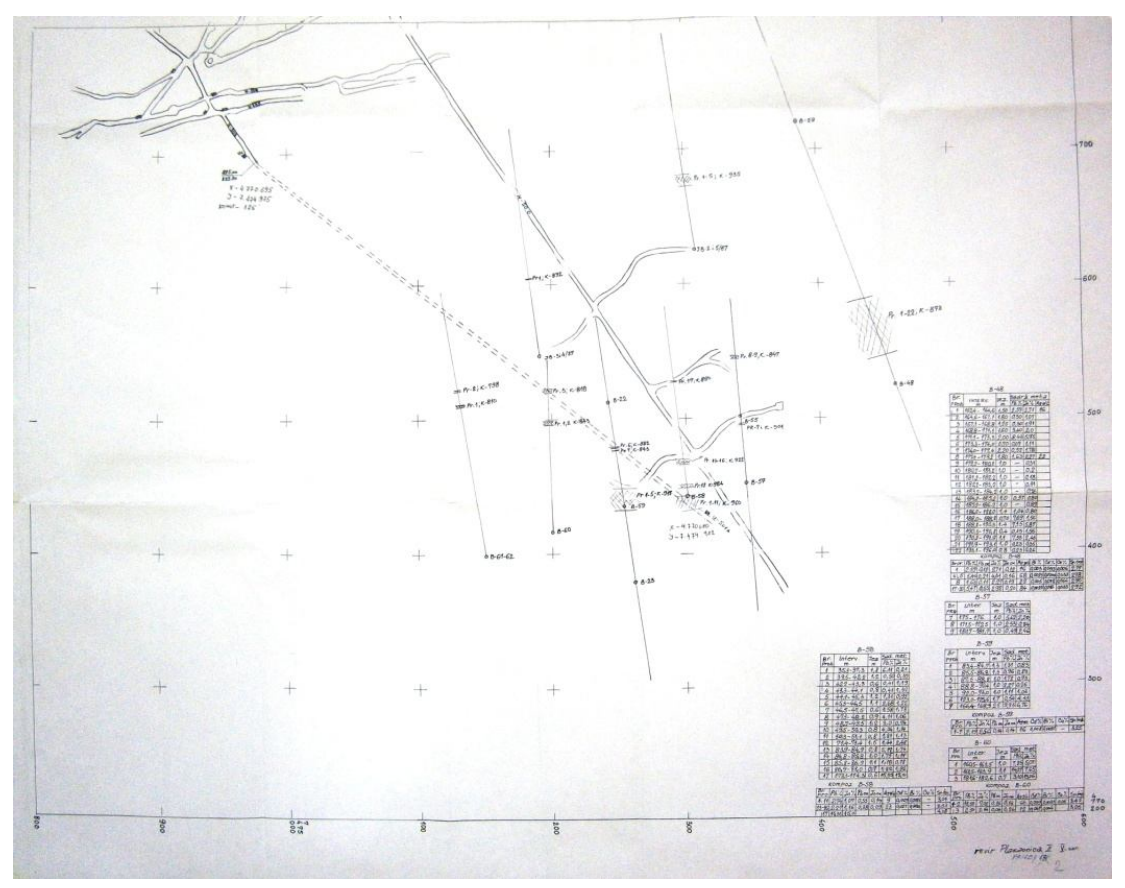

Figure 2 Map of the district PLAKAONICA II with exploratory drill holes and exploratory mining operations

- The third ore interval was drilled in the roof of another quartz latite dike with quartz seratite schists with apparent thickness of $3 \mathrm{~m}$ with $4.75 \%$ lead, $1.95 \%$ zinc and $56 \mathrm{~g} / \mathrm{t}$ silver.

- The fourth ore interval was drilled at the contact of serpentinite in the roof of the amphibolite schists in the floor. The ore was drilled slightly above the horizon IV, the apparent thickness of $3 \mathrm{~m}$ with $6.63 \%$ lead, $4.93 \%$ zinc and $79 \mathrm{~g} / \mathrm{t}$ silver.

By development the adit at the elevation of $945 \mathrm{~m}$ as well as development five new drill holes from surface, the reserves were recategorized in the $\mathrm{C} 1$ category. In five profiles at distance of $50 \mathrm{~m}$, the drill holes B- 57, B - 58 B - 59 and B - 60 were drilled. 
All ore bodies, drilled or opened by exploratory adit at the elevation $945 \mathrm{~m}$, can be generally classified into the following structural morphological types.

a) Ore veins in amphibolitic schists or contact of quartz latite dikes of shales;

b) Stock work-impregnation ore bodies in silicon calcareous mass.

The main conclusion on the basis of all the drill holes and adit, proving the existence of ore bodies in highly complex structural - geological conditions, ore bodies, are difficult to connect in space [4].

- Drill hole B - 57 in two levels drilled two mineral structures; the first mineral structure is located at the level of the II horizon and several mineralizations, apparent thickness of about $10 \mathrm{~m}$, where the contents of lead and zinc are less than $1 \%$. The structure itself is located at the contact of serpentinite and quartz latite.

- The second mineral structure is located immediately below the horizon IV apparent thickness of $1.2 \mathrm{~m}$ at contact of serpentine and schists with the content of $5.62 \%$ lead, $2.2 \%$ zinc [4].

- Drill hole B - 58 drilled the mineralized zone in the range of $16-20 \mathrm{~m}$ at the contact of quartz latite and changing serpentine parties.

- The second mineral structure of apparent thickness of $2.0 \mathrm{~m}$ and content of $1.44 \%$ lead, $2.48 \%$ zinc and $18 \mathrm{~g} / \mathrm{t}$ silver.

- The third drilled mineral structure is on average slightly lower than the fourth horizon level at the contact of quartz latite dike and shale series of apparent thickness of $1.2 \mathrm{~m}$ and very high content of $15.35 \%$ lead, $15 \%$ zinc [4].

- Drill hole B - 59 drilled three mineral structures and nearly all structures are located at the contact of quartz latite dikes and serpentite.

- The first mineral structure of apparent thickness of $10 \mathrm{~m}$ is located over the level of the III horizon with content of $1.10 \%$ lead and $1.03 \%$ zinc.

- The second mineral structure was drilled between the III and IV horizon, apparent thickness of $2.6 \mathrm{~m}$ and content of $0.54 \%$ lead and $4.33 \%$ zinc.

- The third mineral structure was drilled between the IV and V horizon at the contact of quartz latite dike and the zone of schists, apparent thickness of $2.5 \mathrm{~m}$ and economic content of $9.93 \%$ lead and $6.76 \%$ zinc (see Figure 2) [4].

- Drill hole B - 60 drilled two mineral structures below the serpentite sediments in the near vicinity of quartz latite dike with content of $12.51 \%$ lead, $7.02 \%$ zinc and $66 \mathrm{~g} / \mathrm{t}$ silver.

- The second mineral structure was drilled at the level of the $\mathrm{V}$ horizon where the floor and roof of the ore body are in schists and where the metal content is $2.5 \%$ lead, $2.14 \%$ zinc and $12 \mathrm{~g} / \mathrm{t}$ silver, approximate thickness of about $1 \mathrm{~m}$ [4].

- Drill hole B - 61 of $103 \mathrm{~m}$ per depth is in serpentite weakly mineralized, at the contact of serpentite shales at $169 \mathrm{~m}$ there are some occurrences of quartz latite veins where the ore is deposited between them in veins of $20-5 \mathrm{~m}$ thickness. The first important mineralization was drilled several meters below the $\mathrm{V}$ horizon, apparent thickness of $2 \mathrm{~m}$ with the content of $0.94 \%$ lead and $9.54 \%$ zinc [4].

- Drill hole B - 62 did not drill any important mineral structure [4] (Figure 2).

At the site "Plakaonica II" in the area of interest, four pit drill holes were drilled B-2/87, 3/87, 4/87 and 5/87 from the hall No. 238 directed to the mineral structure "PLAKAONICA I" [4].

- Pit drill holes 2/87 and 5/87 were drilled in the same profile with differrent drop angle and show that in the first few meters of drilling have drilled two intervals in amphibolite schists, the first thickness of $7.1 \mathrm{~m}$ with $3.82 \%$ lead and $3.98 \%$ zinc. This ore despite 
the high metal content should not be given too much importance due to the probability that it is not stable per fall and strike. These assumptions are confirmed by drill hole B-5/87 that drilled same ore with thickness of $16.4 \mathrm{~m}$ and where the contents are $1.63 \%$ lead and $0.82 \%$ zinc [4].

In the interval from 301.1 to $310.1 \mathrm{~m}$ was also drilled mineral structure that is not characterized by high content of metals ( $\mathrm{Pb} 1.56 \%$ and $\mathrm{Zn} 0.76 \%)$, but is almost known that these structures belong to the structures "PLAKAONICA I" [4].

Overall assessment the drill holes, both drilled from the surface, and four pit drill holes and exploratory adit at the elevation $945 \mathrm{~m}$ at the locality "PLAKAONICA", it can be concluded that this is a promising area in which an exploratory drift has to be developed at the $\mathrm{V}$ horizon at distance of $420 \mathrm{~m}$ of strike direction $160^{\circ}$ in order to increase the raw material base of the mine and recategorization the reserves into to higher category.

Previous geological explorations of lead and zinc in the mine Crnac, the data were obtained, on the basis on which the ore reserves can be calculated that will serve as a marker for further geological explorations for transfer of reserves in higher categories.

Perspective reserves of $\mathrm{C} 2$ category were estimated in the mineral structures that were confirmed with only one drill holes in the profile or mineral veins as extrapolated to the $\mathrm{C} 1$ category reserves in the areas where structural - geological data indicate a significantly greater extent of mineral structures. In order to plan further explorations, the $\mathrm{C} 1$ reserves are shown in Table 1 wherein the quantity and quality of ore in certain mineral veins are taken approximately as in the neighboring block [4].

Table 1 Ore reserves of Cl category, district PLAKAONICA II

\begin{tabular}{|c|c|c|c|c|c|}
\hline \multirow{2}{*}{ CATEGORY } & \multirow{2}{*}{ DRILL HOLE } & \multirow{2}{*}{ ORE (t) } & \multicolumn{3}{|c|}{ METAL CONTENT } \\
\cline { 4 - 6 } & & & Pb \% & Zn \% & Ag (g/t ) \\
\hline $\mathrm{C}_{1}$ & $\mathrm{~B}-57 ; 58 ; 59 ; 60 ; 61 ; 55$ & 200,000 & 5 & 3.5 & 70 \\
\hline
\end{tabular}

\section{CONCENTRATION OF FURTHER EXPLORATIONS IN THE DISTRICT "PLAKAONICA II" AND EXPECTED RESULTS}

Based on the previous performed exploratory works on this district, the reserves of $\mathrm{C} 1$ category were selected. This category of mineral resources in the district, "PLAKAONICA II" was obtained by drilling the drill holes from surface and mining exploratory works at the horizon II level $945 \mathrm{~m}$. Annex 2 gives a transparent map of exploratory works on "PLAKAONICA II" and pit Crnac, as well as the English adit.

In order to re-categorize the mineral resources from category $\mathrm{C} 1$ to higher category $\mathrm{B}$ or $\mathrm{A}$, it is necessary to do the additional mining operations.

Based on the previous gained experience in the district Crnac and district "PLAKAONICA I" as well as the experience with other similar mines, further exploration mining works that will have the function of undertaking the mining structure by depth and opening the district "PLAKAONICA II" will consist of the following:

- Development of cross drift at least at two levels to the end of the drift H-416 at theIV horizon and from the end of the drift $\mathrm{H}-503$ at the $\mathrm{V}$ horizon, to the data from drill holes B-59 and B-60 in the district "PLAKAONICA II".

- Development the exploratory substratum drifts for individual ore veins per direction of their strike.

- Development of transient transport raises from lower to higher levels per drop of ore veins. 
- Ore reserves, shown in Table 1, by development of exploratory mining works by depth of deposit, can be transferred to a higher category, shown in Table 2 [3].

Table 2 Ore reserves of $B+C 1$ category, district PLAKAONICA II

\begin{tabular}{|c|c|c|c|c|}
\hline \multirow{2}{*}{ CATEGORY } & \multirow{2}{*}{ DRILL HOLE } & \multicolumn{3}{|c|}{ ORE (t) } \\
\cline { 3 - 5 } & & Pb \% & Pb \% & \\
\hline $\mathrm{B}+\mathrm{C}_{1}$ & 956,529 & 8.09 & 2.58 & 116 \\
\hline
\end{tabular}

Such conceptual review the explorations and opening the ore mining district "PLAKAONICA II" is defined from the following reasons:

- Development and opening the district Crnac and district "PLAKAONICA I" have resulted in the assumptions for continuation the explorations in a direction of new districts, in this case the district "PLAKAONICA II". Strike and drop of some ore veins as well as their parallelism, and the location of shaft and central ore chute (COC) in the basement of the ore body, imposed for making this district one of the main transverse corridor, which will connect all future ore veins, with districts "PLAKAONICA II" and Crnac, i.e. with a shaft and central ore chute [3].

- To convert the all drifts and raises into facilities of development, transport, transient ventilation pathways in later stage in the development and exploitation of ore from this mining district [3].

\section{CONCLUSION}

In accordance with geology of the district deposit "PLAKAONICA II", the most favorable selection was made for the location of the main exploratory hall and ventilation drift from the fifth horizon to the IV horizon. Figure 2 presents the position of the main transverse exploratory hall GPIH - 503 and transient ventilation drift PVU - 501 - A.

As already stated, the district "PLAKAONICA II" was identified by exploratory drill holes B -57; B - 58; B -59 and B - 60 as well as drift No. 2 at the level of $945 \mathrm{~m}$. Based on these data, the connection of the results of exploration was carried out from adit No. 2 and thus gain insight into multiple parallel mineralization structures that have to be confirmed mining exploration works. For now, in this district "PLAKAONICA II", four (4) mineral structures were identified that are distant from the existing active mines rooms of $300-400 \mathrm{~m}$. The strike direction of these structures as well as the corners of brooding in depth will be explored by mining operations. Considering the great distance of geological data from the district "PLAKAONICA I" and the length and position of development of the main transverse exploration drift, it is expected to identify several mineral structure to the data from drill holes.

The length of the main transverse drift is determined from drill hole data and they are on limit of spreading to the roof of the deposit since the position of the "PLAKAONICA I" and district Crnac was considered as well as the possibility of connecting the district "PLAKAONICA II" at every horizon with shaft and central ore chute.

\section{REFERENCES}

[1] G. O. Milentijević, Basics of Geology and Engineering Geology, University in Priština, Faculty of Technical Sciencies, 2011, pp. 385-412 (in Serbian);

[2] Technical Documentation of Geological Service RIF - Kopaonik Leposavić (in Serbian);

[3] B. Lj. Nedeljković, G. O. Milentijević, technical Mining Desing of Development the Mining Exploration Operations for the District "PLAKAONICA II", 2013 (in Serbian);

[4] Report on Exploration the Lead-zinc Ore in the Period 1983 to 1994 on Rogozna. Rapporteur Geozavod, Belgrade (in Serbian). 


\begin{tabular}{ll}
\hline \hline INSTITUT ZA RUDARSTVO I METALURGIJU BOR & ISSN: 2334-8836 (Štampano izdanje) \\
UDK: 622 & ISSN: 2406-1395 (Online) \\
\hline \hline
\end{tabular}

\section{MOGUĆNOSTI ISTRAŽIVANJA Pb-Zn RUDE NA REVIRU PLAKAONICA II RUDNIKA CRNAC ${ }^{* *}$}

\section{Izvod}

U okviru racionalnog korišćenja mineralnih sirovina u rudniku Pb-Zn Crnac, kao i redosledu otkopavanja rude po pružanju orudnjenja i po dubini zaleganja, u ovom radu date su mogućnosti proširenja rudnog polja Crnac na okolne revire, u ovom slučaju revira Plakaonica II. Primenjene metodologije istraživanja su geološki istražni radovi i rudarski istražni radovi.

U ovom radu su prikazani rezultati istraživanja dobijeni interpolacijom podataka sa istražnih bušotina i istražnih rudarskih radova na reviru Plakaonica II.

Ključne reči: olovo i cink, istražni radovi, bušenje istražnih bušotina, istražni rudarski radovi, rudne strukture, istraživanje

\section{UVOD}

Područje ležišta „Crnac“ je brdovito i ispresecano dubokim potocima i jarugama. Rudnik „Crnac“ je na relativno maloj nadmorskoj visini od $600-900 \mathrm{~m}$. Nalazi se na planini Rogozni u dolini Crnačke reke, leve pritoke Ibra. Dolinom Jošaničke, odnosno, Crnačke reke u gornjem toku, rudnik „Crnac“ povezan je sa objektima za preradu rude u Leposaviću asfaltnim putem dugim $15 \mathrm{~km}$. Područje rudnog ležišta ima blagu klimu. Obilne padavine u zimskom periodu ne pričinjavaju veće poteškoće prilikom transporta rude.

Ležište "Crnac" otvoreno je nakon intenzivnog desetogodišnjeg istraživanja bušenjem sa površine i rudarskim radovima u periodu od 1957. godine do 1968. godine, od strane geološke službe rudnika i topionice olova i cinka „Trepča“ - Zvečan. Otvaranje rudnika „Crnac“ doprinelo je pove- ćanju sirovinske baze olova i cinka kao osnovnih sirovina za potrebe metalurških postrojenja i novoizgrađenih prerađivačkih kapaciteta Kombinata „Trepča“ na bazi ovih metala. Otvaranje rudnika "Crnac“ sa relativno visokim sadržajem metala olova i cinka veliki je podsticaj razvoju jednog nerazvijenog područja kao što je teritorija opštine Leposavić.

Od početka rada, odnosno od 1968. godine rudnik „Crnac“ nalazi se u sastavu organizacione celine rudnici i flotacija „Kopaonik“ Leposavić. Sadašnje nepovoljno stanje sirovinske baze pomenute organizacione celine kao i Kombinata „Trepča“ u celini, i sve veće potrebe za zadovoljenje prerađivačkih kapaciteta, zahtevaju dalje i intenzivnije istražne radove kako u samom ležištu, tako i u njegovom širem području.

\footnotetext{
* Univerzitet u Prištini sa privremenim sedištem u Kosovskoj Mitrovici, Fakultet tehničkih nauka, Kosovska Mitrovica, Kneza Miloša 7, e-mail: blagojenedeljkovic@yahoo.com

** Izvedeno istraživanje je podržano od strane Ministarstva prosvete, nauke i tehnološkog razvoja Republike Srbije (Projekat br. III 43007, Projekat br. TR 33045)
} 


\section{OPIS LEŽIŠTA}

„CRNAC““ i „PLAKAONCA“ predstavljaju sistem rasednih zona i žica, genetski i vremenski istovetnih, tako da i po vrsti mineralizacije imaju veliku sličnost. Većim delom ruda je odložena u amfibolitima, dok je za sada u serpentinu kvantitativni i kvalitativno ruda podređenog značaja. Rudne žice imaju sočivasta zadebljanja i isklinjavaju kako po pružanju tako i po padu. Često se tanje žice sastaju u nešto deblje žice, da bi se opet razilazile i isklinjavale. Pojedinačno tanke i rudom bogate žice mogu se grupisati u rudne zone, dajući rudna tela moćnosti i do $10 \mathrm{~m}$, sa sadržajem metala u granicama rentabilnosti eksploatacije. Sitnije žice i žičice kao i impregnacije kadkad grade mrežu i daju mineralizaciju štokverhnog tipa [2].

Sistem rudnih žica vezan je za rasedne zone i pukotine, pružanja SI - JZ dok su padovi različiti, rudne žice se nekad divergentno razilaze $u$ dubljim nivoima, jer jedne padaju na SZ, a druge na JI.

Rudna zona vezana za kontakt amfibolita serpentinita ili dijabaz-rožne serije, gde ima i rasednih zona, kao i dacitskih dajkova, imaju pad ka JI. Postoje i rudne žice (primer, rudna žica 3 i 4) koje imaju pad na suprotnu stranu, odnosno padaju prema SZ. Veći broj rudnih žica kao i rudne žice u Plakaoničkom reviru imaju pad prema JI. Padni uglovi rudnih žica su promenljivi i kreću se u granicama između $60^{\circ}$ i $90^{\circ}$.

U rudnoj asocijaciji ležišta „CRNAC” identifikovani su kao bitni minerali galenit, sfalerit i pirit, a podređeno halkopirit, arsenopirit i pirhotin [1]. Od minerala jalovine konstatovane su pretežno kvarc i kalcit, ređe rodohrozit. Pri naknadnim ispitivanjima mikroelemenata indicirano je prisustvo iridijuma $(2-114 \mathrm{~g} / \mathrm{t})$ selena $(4,7 \mathrm{~g} / \mathrm{t}) \mathrm{u}$ pojedinačnim sulfidnim mineralima olova $i$ cinka. Oskudno vršena ispitivanja mineralne parageneze u ležištu pokazuju na osudstvo rudnih i nerudnih minerala karakterističnih za kontaktno-metasomatske ili prelazne kontaktno-metasomatsko-hidrotermalne procese koji su predhodili glavnoj fazi hidrotermalnih procesa u formiranju ležišta. Odsustvo takvih fenomena i procesa koji bi im predhodili pokazuje na uslove stvaranja tipskog hidrotermalnog ležišta mezotermalne faze u kome je odsustvovala višefaznost sa karakterističnim sukcesijama koje karakterišu prelazno konztaktno-metasomatsko hidrotermalna olovo-cinkova ležišta kopaoničkog rudnog reona. Objašnjenja koja se vezuju za raznobojne sfalerite kao dokaz prisutnosti epitermalnih procesa $u$ ležištu nisu dovoljna i trebalo bi ih potkrepiti potpunijim i svestranijim ispitivanjima. Do sada je u ležištu makroskopski sigurno uočeno prisustvo dve sukcesije hidrotermalnog područja deponovanja. Prvo, prerudnoj, odgovaraju procesi deponovanja ogromnih silicitskih i manje silicijskokarbonatnih tvorevina formiranih mahom na račun serpentinita $u$ njihovom kontaktu sa gabroamfibolitima i vulkanskim pokrovom u ležištu i na Rogozni. Ovu asocijaciju stena izrađuju pretežno opalsko-kalcedonske mase i amorfne silicije sa većim ili manjim koncentracijama pirita, koja se u celini može smatrati sterilnom sa ekonomskog stanovišta. Drugu glavnu fazu deponovanja reprezentuju opisani rudni minerali mezotermalne faze sa ekonomskim oruđenjima olova i cinka čija se koncentracija u pogodnim strukturama silicijskih masa manifestuju kao rudna tela sa ekonomskim sadržajima korisnih metala [2].

Obzirom na utvrđene sukcesije i mineralnu paragenezu, pozicionu vezu ležišta i rudnih tela sa vulkanskim probojima tercijarne starosti i jasne hidrotermalne procese koji se približavaju uslovima i ležištima rudnog polja Koporić - Jelakce ležište je svrstano u tip hidrotermalnih ležišta dominantno mezotermalne sukcesije genetski vezano za proces tercijarne metalogenije. 


\section{OTVARANJE LEŽIŠTA CRNAC}

Otvaranje ležišta CRNAC (slika 1) je vršeno u dve faze. Prva faza u period od 1957 - 1968. god. i obuhvata nivo iznad 862 m i druga faza otvaranja od 1968 - 1980. god. od nivoa 600 m - Gnježdanskog potkopa [3].

Rudno ležište "CRNAC" iznad nivoa $862 \mathrm{~m}$ otvoreno je sistemom potkopa, koji $\mathrm{u}$ isto vreme predstavljaju i nivoe horizonata rudnika i to [3]:

- 0 - horizont na koti $1.062 \mathrm{~m}$

- I - horizont na koti 996,2 m

- II - horizont na koti $944,7 \mathrm{~m}$

- III - horizont na koti 902 m

- IV - horizont na koti $862 \mathrm{~m}$

Prvi, drugi i četvrti horizont otvoreni su potkopima sa površine (date kote se odnose na kote ulaza u potkope), a dok je treći horizont otvoren sa IV horizonta sistemom uskopa kao međuhorizont [3].

Idući od ulaza potkopa br. 4 (kota 862) ekonomski značajnije žice su označene rednim brojevima od $1-17$. Kao što je već rečeno, imaju pad ka JI vrlo strmo sa padnim uglom oko $80^{\circ}$. One imaju iste morfološke karakteristike kao i ostale rudne žice i ostaje kao najvažnije njihova osobina da relativno dobro zadržavaju kontinuitet, kako po pružanju tako i po padu [3].

Četvrti (IV) horizont je dugo vremena bio osnovni horizont, jer se po njemu obavljao celokupni transport rude, izvoz rude na površinu vršio se preko ovog potkopa. Pored toga, sa IV horizonta vršila se skoro cellokupna dostava materijala potrebnog za rad, osnovna energetska mreža je i sada na ovom horizontu (komprimirani vazduh, tehnička voda i elektro energija) [3].

Otvaranje ležišta ispod nivoa $862 \mathrm{~m}$ urađeno je sistemom rudarskih radova kapitalnog značaja za ceo rudnik a u cilju poduhvatanja dubinskog dela ležišta. $U$ tu svrhu urađen je potkop Gnježdane dužine $3.781 \mathrm{~m}$. Slepo servis okno sa nivoa
$600 \mathrm{~m}$ do nivoa $862 \mathrm{~m}$ iz kojeg su urađena šest navozišta i to [3]:

- IV - horizont (K. 867,00 m)

- V - horizont (K. 818,00 m)

- VI - horizont (K. 768,00 m)

- VII - horizont (K. 718,00 m)

- VIII - horizont (K. 668,00 m)

- IX - horizont (K. 609,89 m) odvozište na nivou potkopa

Izvozna mašina sistema "KEPE" nalazi se u hali koja se nalazi neposredno iznad tornja, a na $23,5 \mathrm{~m}$ iznad navozišta na IV horizontu [3].

Centralna rudna sipka - kojom se celokupna ruda iz jame spušta na nivo IX horizonta - na nivo potkopa “GNJEŽDANE" [3].

\section{STEPEN ISTRAŽENOSTI REVIRA "PLAKAONICA II"}

Istraživanje ove rudne strukture rađeno je u periodu od 1983. Do 1994. godine. Jedan veliki broj bušotina urađen je pre otvaranja rudnika "CRNAC". U cilju definisanja rudnih struktura koje se nalaze južno od engleskog potkopa. Godine 1983. urađene su četiri bušotine (B -55, B - 54, B - 53 i B - 52) u tri profila, čiji su rezultati pozitivni odnosno sve su u nekoliko nivoa presekle rudne strukture, ali sa nedovoljnim brojem podataka za proračun rezervi. Izradi novih istražnih bušotina sa površine pristupilo se 1994. godine, a sve u cilju boljeg definisanja istražnog prostora kao i prekategorizacije rudnih rezervi [3].

Bušotinama B -55, B - 56, B - 57, B-58 i B -59 u četiri profila na rastojanju od 50 $\mathrm{m}$, dobijeni su pozitivni rezultati. Svih pet bušotina nabušile su po nekoliko rudnih struktura, što je omogućilo da se reserve C2 kategorije prevedu u višu $\mathrm{C} 1$ kategoriju. Izradom potkopa na koti $945 \mathrm{~m}$ i jamskim bušotinama iz tog potkopa B-1/87, B-2/87, B-3/87, B-4/87 koje imaju smer bušenja 
prema PLAKAONICI I, odnosno rudnoj žici 13 i 15, iz profila se može zaključiti da postoji jedan širi sterilni prostor između ove dve rudne strukture (slika 2) [3].

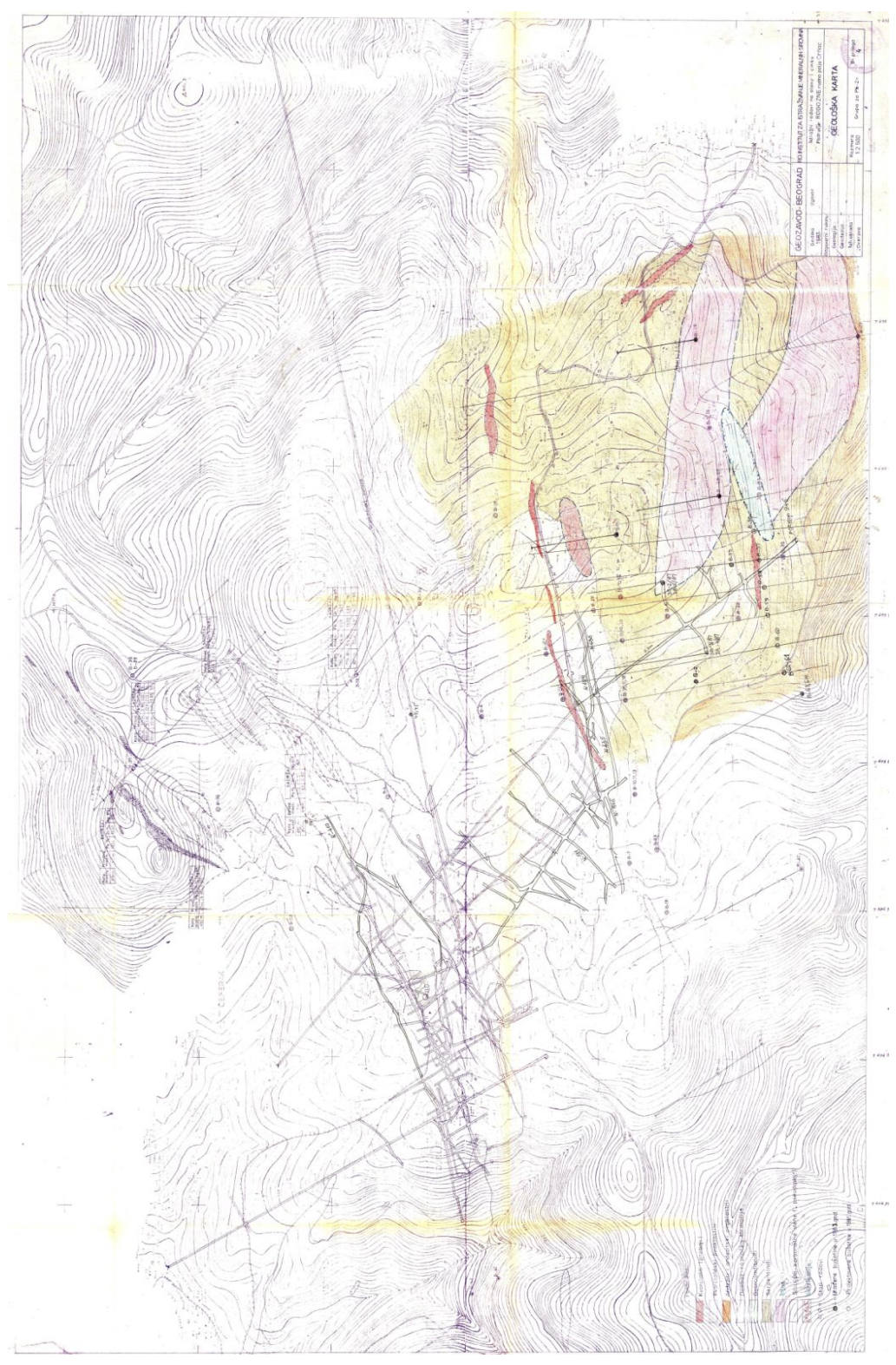

SI. 1. Karta ležišta sa situacionim planom jame CRNAC sa navedenim horizontima

U 1984. godini u ovom reviru urađene su četiri bušotine B - 52, B - 53, B - 54 i B - 55 . Dobijenim podacima iz ovih bušotina utvr- đene su rezerve $\mathrm{C} 2$ kategorije 498.600 t rude sa $4,41 \%$ olova, $4,12 \%$ cinka i $51 \mathrm{~g} / \mathrm{t}$ srebra [4] 
Prostorno gledano osim bušotine $\mathrm{B}-55$ druge tri su po nekoliko stotina metara udaljene od projektovanog hodnika u reviru "PLAKAONICA II". Međutim, sve navedene bušotine su u više nivoa presekla po nekoliko orudnjenja sa značajnim ekonomskim sadržajima metala [4].

- Bušotina B - 55 projektovana je sa ciljem da proveri pružanje rudne strukture nabušene bušotinom B - 48 . Bušotina je bušila serpentin, dva kvarclatitska dajka, anfibolitski škriljac, gnajseve i četiri ekonomski značajna rudna intervala

- Prvi rudni interval i najmoćniji bušen je na dubini od 49,8 - 70,8 m prividne moćnosti od $23 \mathrm{~m}$ i sadržaj metala u rudi je 5,51\% olova, 4,21\% cinka i $47 \mathrm{~g} / \mathrm{t}$ srebra. Prostorna ruda je deponovana $\mathrm{u}$ intenzivno silifikovanom serpentinitu (silicijsko - karbonatskoj steni) na kontaktu sa kvarclatitom.

- Drugi interval prividne mogućnosti od oko $4 \mathrm{~m}$ sa sadržajem metala od 4,0 \% olova, 4,09 \% cinka i $58 \mathrm{~g} / \mathrm{t}$ srebra.

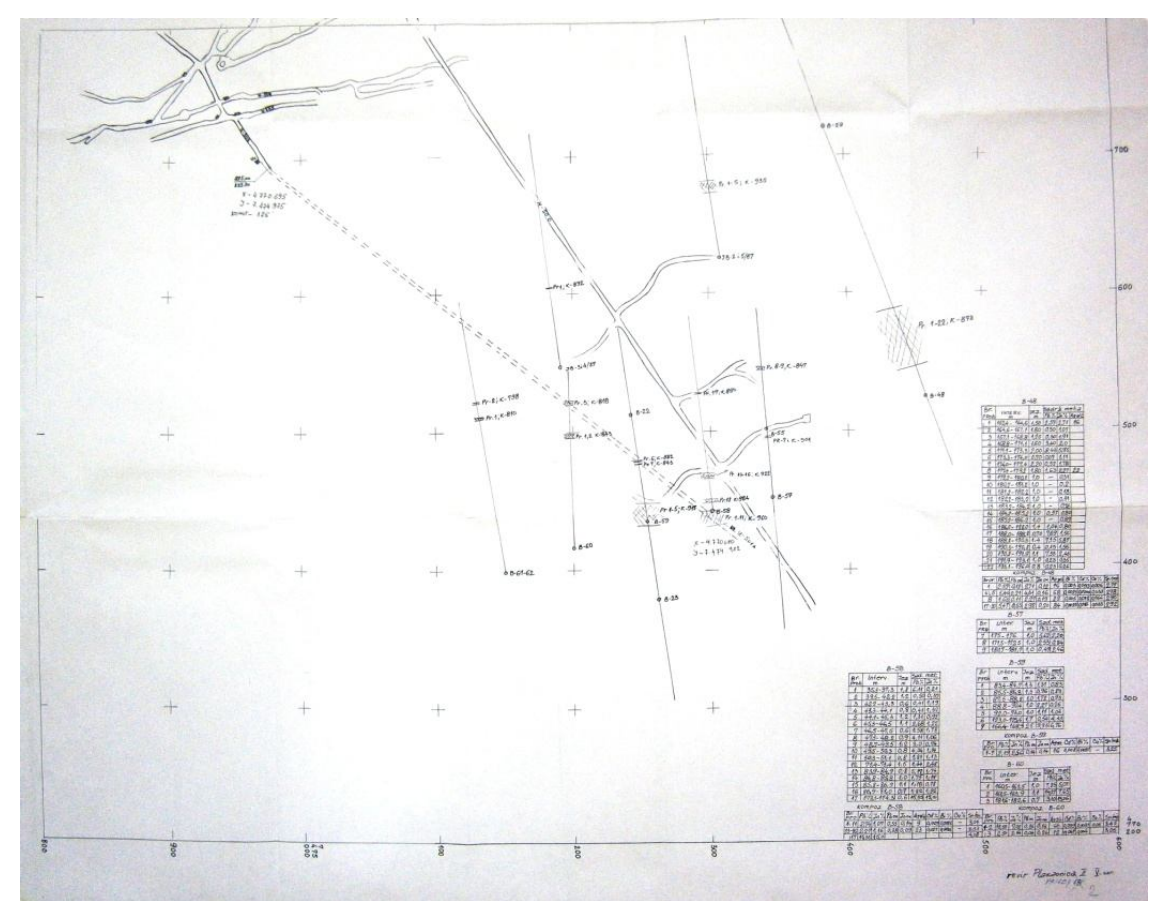

Sl. 2. Karta revira PLAKAONICA II sa istražnim bušotinama i istražnim rudarskim radovima

- Treći rudni interval nabušen je $u$ povlati drugog kvarclatitskog dajka sa kvarcseratitskim škriljcima prividne moćnosti moćnosti $3 \mathrm{~m}$ sa $4,75 \%$ olova, $1,95 \%$ cinka i $56 \mathrm{~g} / \mathrm{t}$ srebra.

- Četvrti rudni interval nabušen je na kontaktu serpentinita $u$ povlati $i$ amfi-bolitskih škriljaca u podini. Ruda je nabušena nešto iznad IV ho- rizonta, prividne moćnosti $3 \mathrm{~m}$ sa $6,63 \%$ olova, 4,93\% cinka i $79 \mathrm{~g} / \mathrm{t}$ srebra.

Izradom potkopa na koti 945 m kao i izradom pet novih bušotina sa površine rezerve su prekategorisane u $\mathrm{C} 1$ kategoriju. U pet profila na rstojanju od $50 \mathrm{~m}$ izbušene su bušotine B-57, B-58, B-59 i B-60. 
Sva rudna tela nabušena ili otvorena istražnim potkopom na koti $945 \mathrm{~m}$ mogu se uopšteno uvrstiti u sledeće strukturno morfološke tipove.

a) Rudne žice $u$ amfibolitskim škriljcima ili na kontaktu kvarclatitskih dajkova škriljaca;

b) Štokverno-impregnaciona rudna tela u silicijsko-karbonatnoj masi.

Osnovni zaključak sagledavajući sve bušotine i potkop, dokazuju postojanje rudnih tela u veoma složenim strukturnogeološkim uslovima, rudna tela se teško mogu povezati u prostoru [4].

- Bušotina B-57 je u dva nivoa nabušila dve rudne strukture; prva rudna struktura nalazi se u nivou II horizonta i više je mineralizacija, prividne moćnosti oko $10 \mathrm{~m}$, gde su sadržaji olova i cinka manji od $1 \%$. Sama struktura nalazi se na kontaktu serpentinita $\mathrm{i}$ kvarclatita.

- Druga rudna struktura nalazi se neposredno ispod IV horizonta prividne moćnosti od 1,2 $\mathrm{m}$ na kontaktu serpentina i škriljaca sa sadržajem od $5,62 \%$ olova, $2,2 \%$ cinka[4].

- Bušotina B - 58 je u intervalu od 16 $20 \mathrm{~m}$ probušila mineralizovanu zonu na kontaktu kvarclatita i promenljivih serpentinskih partija.

- Druga rudna struktura prividne moćnosti 2,0 $\mathrm{m}$ i sadržajem od 1,44\% olova, $2,48 \%$ cinka i $18 \mathrm{~g} / \mathrm{t}$ srebra.

- Treća nabušena rudna struktura prosečno je nešto niža od nivoa četvrtog horizonta na kontaktu kvarclatitskog dajka i serije škriljaca prividne moćnosti od $1,2 \mathrm{~m}$ i veoma visokim sadržajem 15,35 \% olova, $15 \%$ cinka [4]

- Bušotina B - 59 je nabušila tri rudne strukture i gotovo sve struktire nalaze se na kontaktu kvarclatitskih dajkova i serpentinita.

- Prva rudna struktura je mineralizacija prividne moćnosti od $10 \mathrm{~m}$ iznad nivoa III horizonta sa sadržajem 1,10\% olova i $1,03 \%$ cinka.
- Druga rudna struktura nabušena je između trećeg i četvrtog horizonta, prividne moćnosti $2,6 \mathrm{~m}$ i sadržajem od $0,54 \%$ olova i $4,33 \%$ cinka.

- Treća rudna struktura nabušena je između IV i V horizonta na kontaktu kvarclatitskog dajka i zone škriljaca, prividne moćnosti od 2,5 m i ekonomskim sadržajem od $9,93 \%$ olova i 6,76 $\%$ cinka (Vidi prilog br. 2) [4]

- Bušotina B - 60 je nabušila dve rudne strukture ispod serpentinskih sedimenata $\mathrm{u}$ neposrednoj blizini kvarclatitskog dajka.

- U sadržajem od 12,51 \% olova, 7,02 \% cinka i $66 \mathrm{~g} / \mathrm{t}$ srebra.

- Druga rudna struktura presečena je na nivou $\mathrm{V}$ horizonta gde su $\mathrm{i}$ podina $\mathrm{i}$ krovina rudnog tela u škriljcima i gde je sadržaj metala olova 2,5\%, 2,14\% cinka i $12 \mathrm{~g} / \mathrm{t}$ srebra, približne moćnosti od oko $1 \mathrm{~m}$ [4].

- Bušotina B - 61 od 103 m po dubini je u serpentinitima koji su slabije mineralizovani, na kontaktu serpentin škriljac na $169 \mathrm{~m}$ imamo nekoliko pojava kvarclatitskih žica između kojih je deponovana ruda u žicama od $20-5 \mathrm{~cm}$ moćnosti. Prvo značajnije orud-njenje nabušeno je nekoliko metara ispod $\mathrm{V}$ horizonta, prividne moćnosti od $2 \mathrm{~m}$ sa sadržajem od $0,94 \%$ olova i $9,54 \%$ cinka [4].

- Bušotina B - 62 nije nabušila ni jednu značajniju rudnu strukturu [4] (slika 2).

Na lokalitetu "Plakaonica II" na prostoru koji je predmet našeg interesovanja izbušene su i četiri jamske bušotine B-2/87, 3/87, 4/87 i 5/87 iz hodnika $\mathrm{N}^{0} 238$ usmerene prema rudnoj strukturi "PLAKAONICA I" [4].

- Jamske bušotine 2/87 i 5/87 bušene su u istom profilu sa različitim padnim uglom i pokazuju da u prvim metrima bušenja nabušena su dva intervala $u$ anfibolitskim škriljcima, prvi moćnosti 
od $7,1 \mathrm{~m}$ sa $3,82 \%$ olova i $3,98 \%$ cinka. Ovoj rudi i pored visokog sadržaja metala ne treba davati preveliki značaj zbog verovatnoće da nije postojana po padu i pružanju. Ove pretpostavke potvrđuje bušotina $B-5 / 87$ koja ovu istu rudu buši sa 16,4 m moćnosti i gde su saržaji $1,63 \%$ olova i $0,82 \%$ cinka[4].

U intervalu od 301,1 - 310,1 m takođe je nabušena rudna struktura koja se ne odlikuje visokim sadržajem metala $(\mathrm{Pb}$ $1,56 \%$ i $\mathrm{Zn} 0,76 \%$ ) ali je gotovo izvestno da ove strukture pripadaju strukturama "PLAKAONICA I" [4].

Sve ukupnim sagledavanjem bušotina, kako onih izbušenih sa površine, tako i četiri jamske bušotine i istražnog potkopa na koti $945 \mathrm{~m}$ na lokalitetu "PLAKAONICA", može se zaključiti da je ovo perspektivna zona, na kojoj treba izraditi istražni hodnik
$\mathrm{Na} \mathrm{V}$ horizontu u dužini od $420 \mathrm{~m}$ pravca pružanja $\mathrm{v} 160^{\circ} \mathrm{u}$ cilju uvećanja sirovinske baze rudnika i prekategorizacije rezervi u višu kategoriju.

Dosadašnjim geološkim istraživanjima olova i cinka u rudniku "CRNAC" dobijeni su podaci na osnovu kojih mogu se procenjivati rudne rezerve koje će služiti kao putokaz za dalja geološka istraživanja, radi prevođenja rezervi u više kategorije.

Perspektivne rezerve $\mathrm{C} 2$ kategorije procenjene $\mathrm{u}$ rudnim strukturama koje su potvrđene sa samo jednom bušotinom u profilu ili u rudnim žicama kao ekstrapolovane na rezerve $\mathrm{C} 1$ kategorije $\mathrm{u}$ prostorima gde strukturno - geološki podaci ukazuju na znatno veće prostiranje rudnih struktura. Radi planiranja daljih istraživanja $\mathrm{C} 1$ rezerve prikazane su u Tabeli 1 pri čemu su količine i kvalitet rude u pojedinim rudnim žicama uzeti približno kao u susednom bloku [4].

Tabela 1. Rezerve rude C1 kategorije, revir PLAKAONICA II

\begin{tabular}{|c|c|c|c|c|c|}
\hline \multirow{2}{*}{ KATEGORIJA } & \multirow{2}{*}{ BUŠOTINA } & \multirow{2}{*}{ RUDA (t) } & \multicolumn{3}{|c|}{ SADŘ̌AJ METALA } \\
\cline { 4 - 6 } & & & Pb \% & Zn \% & Ag (g/t ) \\
\hline $\mathrm{C}_{1}$ & $\mathrm{~B}-57 ; 58 ; 59 ; 60 ; 61 ; 55$ & 200.000 & 5 & 3,5 & 70 \\
\hline
\end{tabular}

\section{KONCENTRACIJA DALJIH \\ ISTRAŽIVANJA U REVIRU \\ "PLAKAONICA II" I \\ OČEKIVANI REZULTATI}

$\mathrm{Na}$ osnovu do sada urađenih istražnih radova na ovom reviru, izdvojene su rezerve C1 kategorije. Do ove kategorije mineralnih sirovina na reviru "PLAKAONICA II" došlo se bušenjem bušotina sa površine i rudarskim istražnim radovima na nivou horizonta II nivoa $945 \mathrm{~m}$. Na Prilogu 2 data je pregledna karta istražnih radova na "PLAKAONICI II" i jame "CRNAC", kao i Engleski potkop.

Da bi se izvršila prekategorizacija mineralnih sirovina iz kategorije $\mathrm{C} 1 \mathrm{u}$ višu kategoriju B ili A potrebno je uraditi dodatne rudarske radove.

$\mathrm{Na}$ osnovu do sada stečenog iskustva na reviru "CRNAC" i revira "PLAKAONI-
CA I" kao i iskustva sa drugih sličnih rudnika dalji istražni rudarski radovi koji će imati funkciju poduhvatanja rudarskih struktura po dubini i otvaranja revira "PLAKAONICA II" a sastojaće se u sledećem:

- Izrada prečnog hodnika na najmanje dva nivoa i to od kraja hodnika $\mathrm{H}$ 416 na IV horizontu i od kraja hodnika H-503 na V horizontu, do podataka sa bušotina B - 59 i B - 60 na reviru "PLAKAONICA II".

- Izrada istražnih podinskih hodnika za pojedine rudne žice po pravcu pružanja istih.

- Izrada prolazno transportnih uskopa od nižih ka višim nivoima po padu rudnih žica. 
- Rudne rezerve prikazane u Tabeli 1, izradom istražnih rudarskih radova po dubini ležišta mogu se prevesti u višu kategoriju prikazano u Tabeli 2 [3].

Tabela 2. Rezerve rude $\mathrm{B}+\mathrm{C}_{1}$ kategorije, revir PLAKAONICA II

\begin{tabular}{|c|c|c|c|c|}
\hline \multirow{2}{*}{ KATEGORIJA } & \multirow{2}{*}{ RUDA $(\mathbf{t})$} & \multicolumn{3}{|c|}{ SADRŽAJ METALA } \\
\cline { 3 - 5 } & & $\mathbf{P b} \%$ & Zn \% & $\mathbf{A g}(\mathbf{g} / \mathbf{t})$ \\
\hline $\mathrm{B}+\mathrm{C}_{1}$ & 956.529 & 8,09 & 2,58 & 116 \\
\hline
\end{tabular}

Za ovakav koncepcijski prikaz istraživanja i otvaranja rudnog revira "PLAKAONICA II" opredeljeno je iz sledećih razloga:

- Razradom i otvaranjem revira "CRNAC" i revira "PLAKAONICA I" stvorene su predpostavke za nastavak istraživanja u pravcu novih revira u ovom slučaju revira "PLAKAONICA II". Pružanje i padovi pojedinih rudnih žica kao i njihova paralelnost, te lokaciju okna i centralne rudne sipke (CRS) u podini rudnog ležišta, nameću i za ovaj revir izradu jednog magistralnog prečnog hodnika, koji će međusobno povezati sve buduće rudne žice, uz istovremeno spajanje revira "PLAKAONICA II" sa revirima "CRNAC" i revira "PLAKAONICA I" odnosno, sa oknom i centralnom rudnom sipkom [3].

- Da se u kasnijoj fazi pri razradi i eksploataciji rude sa ovog revira, mogu se prostorije za istraživanje pre svih hodnici i uskopi pretvoriti u objekte razrade, transporta, prolazne i ventilacione puteve [3].

\section{ZAKLJUČAK}

Saglasno geologiji ležišta revira "PLAKAONICA II" izvršen je najpovoljiji izbor lokacije glavnog prečnog istražnog hodnika i pročazno ventilacionog uskopa od petog $\mathrm{V}$ horizonta do IV horizonta. Na prilogu 2 dat je položaj glavnog prečnog istražnog hodnika GPIH - 503 i prolazno ventilacionog uskopa PVU - 501 - A.

Kao što je već rečeno revir "PLAKAONICA II" identifikovan je istražnim bušotinama $\mathrm{B}-57$; B - 58; B -59 i B -60, kao i potkopom br. 2 na nivou $945 \mathrm{~m}$. Na osnovu ovih podataka izvršeno je spajanje rezultata sa istražnih bušotina sa potkopa br. 2 i time stekli uvid u više paralelnih struktura rude koje treba potvrditi rudarskim istražnim radovima. $\mathrm{Za}$ sada na reviru "PLAKAONICA II" imamo identifikovanih (4) četiri rudne strukture koje su udaljene od postojećih aktivnih prostorija rudnika od $300-400 \mathrm{~m}$. Pravac pružanja ovih struktura kao i uglovi zaleganja po dubini istražiće se rudarskim radovima. Imajući u vidu veliku udaljenost geoloških podataka od revira "PLAKAONICA I" i dužinu i položaj izrade glavnog prečnog istražnog hodnika očekuje se identifikacija još nekoliko rudnih struktura do podataka sa bušotina.

Dužinu glavnog prečnog hodnika određuju podaci sa bušotina i oni su na granici prostiranja prema krovini ležišta s tim što je ovde vođeno računa o položaju revira "PLAKAONICA I" i revira "CRNAC" i mogućnost povezivanja revira "PLAKAONICA II" na svakom horizontu sa oknom i centralnom rudnom sipkom.

\section{LITERATURA}

[1] G. O. Milentijević, Osnove geologije i inženjerske geologije, Univerzitet $u$ Prištini, Fakultet tehničkih nauka, 2011, str. 385-412.

[2] Tehnička dokumentacija geološke službe RIF - Kopaonik Leposavić

[3] B. Lj. Nedeljković, G. O. Milentijević, Tehnički rudarski projekat izrade rudarskih istražnih radova za revir "PLAKAONICA II", 2013.

[4] Izveštaj o istraživanju olovno-cinkove rude u periodu 1983. do 1994. godine na Rogozni, Izvestioc Geozavod Beograd. 